\title{
ANTIMICROBIAL ACTIVITY OF SOME BIOACTIVE PLANT MATERIALS
}

\author{
M Gobalakrishnan \\ Assistant Professor level III, \\ Department of Textile Technology, \\ Bannari Amman Institute of Technology, \\ Sathyamangalam, Erode District, Tamil Nadu, India.
}

\author{
A Gowrisankar, M Vignesh, P A Kowshikan \\ Student, Department of Textile Technology, \\ Bannari Amman Institute of Technology, \\ Sathyamangalam, Erode District
}

\begin{abstract}
The natural medical plant play important role in human health care development. In India about 70 percent of rulal population are depend on traditional Ayurvedic medicines. So, natural medicine plant or traditional medicine is a best alternative of modern medicine. India is top of the producer of medicinal plants. There are currently about $\mathbf{2 5 0 , 0 0 0}$ registered medical plants are in India (Pandey, Rastogi, and Rawat 2013). Nowadays, medical plants play a dominant role in antimicrobial textiles. The compounds like alkaloids, flavanoids, glycosides, resins, phenolic compounds, fales and oils present in the medicinal plants are responsible for antimicrobial activity. These natural compounds derived from the plants are non-toxic and eco-friendly nature. Gram negative and gram positive bacteria are unhealthy and cause disease when it spread into human body. Although most bacteria are harmless some are pathogenic which cause disease in humans. In this paper some natural bio active materials like, Citrus lemon, Garlic, Baeckea frutescens, Neem and Eclipta Alba, used for antimicrobial activity are discussed.
\end{abstract}

Keywords - Antimicrobial activity, herbal, bioactive compounds, medicinal plants, cotton fabric, citrus lemon, garlic, Neem.

\section{INTRODUCTION}

Various natural bioactive materials are available in world wide. Each material has its own properties. Some bioactive materials has very good antimicrobial properties (Pandey, Rastogi, and Rawat 2013). In this article, the compounds present and responsible for antimicrobial properties and the application of bioactive materials, Citrus lemon, Garlic, Baeckea frutescens, Neem and Eclipta Alba, on cotton fabric are described.

\section{A. Antimicrobial activity of Citrus Lemon}

Lemon used in house as medicine for many medical issues and it is from Rutacease family. The lemon having the alkaloids and it has the power to cure cancer (Kadhim Hindi and Ghani
Chabuck 2013). So it used to prepare the anticancer activities. The lemon has the potential of antimicrobial activity of the extracts of all the parts of the plants (Kawaii et al. 2000). The lemon has citrus flavonoids in addition to the alkaloids. This citrus flavonoids have the wide spectrum of biological activity (Burt 2004; Ortuño et al. 2006). Flavonoids act as the antioxidants and inhibit cell proliferation (Duthie Garrya and Crozier Alan n.d.). The plant has Flavonoids in the form of glycosylated, and the important factor for determining the bioavailability is their sugar moiety. To minimize the central nervous system disorder, the extracts of bitter orange of various parts, peel, flowers, and leaves are used (De Moraes Pultrini, Almeida Galindo, and Costa 2006). The peel of Citrus fruits is a rich source of flavonoid glycosides and volatile oils (Shahanaz sultana et al. 2007). The bioactive compounds, polyphenols, the important vitamin $\mathrm{C}$ to cure the vitamin $\mathrm{C}$ deficiency also present in the fiber of citrus fruit (Dhanavade et al. 2011). The literature shows that the compounds, essential oils, corydaline and protopine alkaloids, acyclic sesquiterpenes, polyacetylene, lactons, pseudohypericin and hypericin present in citrus lemon are effective in wide range of bacteria. The other compounds, the alcohols, terpenes, aldehydes and ester are also contribute the overall antimicrobial acitivity (Keleş et al. 2001).

Maruti J. Dhanavade et al, used lemon peel for antimicrobial properties. The peels of lemon were separated and dried under sunshades. Dried peels converted into fine powder by crushing in an electric blender. The solvents, ethanol, methanol and acetone are used for extraction of lemon peel. The microorganism used for this antimicrobial activity are Pseudomonasaeruginosa, Salmonella typhimurium, and Micrococcus aureus. The result shows that the lemon peel exhibits good antimicrobial activity (Dhanavade et al. 2011). The essential oils present in the lemon exhibits to inhibit the growth of the microorganisms, moulds $\mathrm{P}, \mathrm{A}$. niger chrysogenum, A. flavus and P. verrucosum (Viuda-Martos et al. 2008). Giuseppe et al., (2007) have reported the presence of limonoids in Citrus species have the antimicrobial properties (Gattuso et al. 2007). Limonoids exhibits good antifungal and antimicrobial properties obtained in C. limon. 


\section{International Journal of Engineering Applied Sciences and Technology, 2020 Vol. 4, Issue 12, ISSN No. 2455-2143, Pages 199-204 \\ Published Online April 2020 in IJEAST (http://www.ijeast.com)}

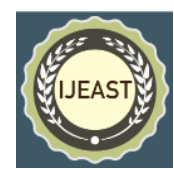

The Citrus fruit lemon, orange and grape fruit are used as the natural antimicrobial agents for food products (Corbo et al. 2008). There are several Citrus (C.) species, of these $C$. limon (lemon), C. limetta (sweet lemon), C. aurantium (bitter orange, $C$. paradise (grape fruit)), and C. jambhiri (Rough lemon) showed antimicrobial properties (Waidulla N Al-Ani, Siba M Al-Haliem, and Nahla O Tawfik 2010).

Syed Qutaba Bin. Tariq et al (2017), used 100\% pure bleached cotton fabric with plain weave construction. The mass per unit weight of the cotton fabric was around $120 \mathrm{gsm}$. The fabric was applied with waste fruit material. Lemon and orange peel were used for extraction. Before extraction, the peels were dried in shade and made into powder. The powders were used to extract the core ingredients from the peel. The extracts of lemon and orange peel are applied on cotton fabric by exhaust method. He used sodium bi carbonate as binder and it improves the durability of the finishing. The lemon and orange fruit waste extracts increases the antimicrobial activity (Qutaba et al. 2017).

Padma S. Vankar et al., used lemon leaves (Citrus limon) as biomaterial for production of nanocomposites to produce the antimicrobial textiles. Lemon extracts act as a reducing agent and silver nano particles act as a core material. The bio synthesis of silver nano composites using the bioactive material, lemon extracts increases the efficiency of the antimicrobial properties (Vankar and Shukla 2012).

\section{B. Antimicrobial activity of Garlic (Allium Satinum)}

Garlic (Allium satimm) is a member of the Lilliaceae family. The other materials comes under this family are onions, leeks and chives. The garlic has the bioactive properties like, antimicrobial, antilipidemic, antioxidant, detoxification, anticoagulant, anticarcinogen, antihypertensive properties (Rees et al. 1993). The other medicinal properties of garlic is also reported in many articles and these medicinal properties is mainly due to the presence of sulphides in the oil of garlic(Tsao and Yin 2001).

The main constituents of garlic is Diallyl monosulphide and diallyl disulphide, is responsible for the medicinal properties of the garlic (Tsao and Yin 2001). It has been reported 54.5\% of total sulphides were present in the garlic oil. Out of which, diallyl tri sulphades and diallyl tetra sulphades accounted around $26 \%$, responsible for medicinal properties (Tsao and Yin 2001). In folk medicine, the Allium satiwm L. is used to cure many diseases. The garlic has various bioactive compounds like alliin, allicin, alliinase, diallylsulphide, Sallycystein, and allymethyltrisulphide. The presence of allicin and tiosulphonates attribures to inhibit the growth of bactericidal activity (Adetumbi, Javor, and Lau 1986; Ishikawa et al. 1996; Luigina Cellini et al. 1996; Shashikanth, Basappa, and Murthy 1984).

Garlic exhibits the good antimicrobial activity against the most Susceptible bacteria include S.aureus (Huddleson I.F et al. 1944), E.coli.(Jezpwa L, Rafinski T.J, and Wrocinski T 1966), and so many (V. . Sharma et al. 1977). Antifungal activity of garlic also good against the dermatophytes (Amer, Taha, and Tosson 1980), Cryptococcus sp (Fromtling $\mathrm{R}$ and Bulmer G.S. 1978). Antonio Marques et al, studied the effect of thermal variation on antimicrobial activity against the microbes S. enterica of garlic and he reported that the garlic has good antimicrobial properties at low temperatures. He also reported that the Oregano has strong antimicrobial properties than garlic (Marques et al. 2008). Susumu Yoshida et al., studied the antimicrobial activity of the Ajoene derived from garlic. The report exhibits strongest antimicrobial properties were obtained by Ajoene, a derived product of garlic (Yoshida et al. 1987).

\section{Antimicrobial activity of Baeckea Frutescens}

Myrtaceae is the family and Myrtoideae is the sub family of the medicinal plant Baeckea frutescens L. The plant has been used as an traditional medicine in South East Asia and the essential oil present in the plant contribute to the medicinal use (Razmavar et al. 2014). The small tree, Baeckea frutescens L. found in Hong Kong, South China and Australia. The plant is also called as "Cucur Atap." in malay. The leaves are very small and narrow and look like as needle and it is about 6-15 $\mathrm{mm}$ long. The leaves produces resinous aromatic fragrance when it is crushed. In china, to treat the fever, tea is made from the extracts of these leaves (S. Mardisiswojo and $\mathrm{H}$. Rajakmangunsudarso 1985). In Indonesia, it has been used as the traditional folk medicine (S. Mardisiswojo and $\mathrm{H}$. Rajakmangunsudarso 1985). For colic diseases, these leaves are burned and the smoke is given the sufferers (Razmavar et al. 2014).

The oil made from these leaves used for aroma therapy and is used to cure mental clarity and mental distress by inhale of the smoke of these leaves (Setzer et al. 2004). For massaging and to release pain from body, the oil made from these leaves are used (Setzer et al. 2004). The presence of phenolic compounds and flavonoids in Baeckea frutescens L. is revealed by Phytochemical method. The alkaloids are known to prepare analgesics, antimalarial and stimulantsand to control the tumor growth, the flavonoids are used (J.A.Dukeand and E.S.Ayensu 1985). Razmavar et al., in 2014, used the extracts of Baeckea frutescens L. to analyse the antimicrobial activity and it shows good antimicrobial activity angainst the Staphylococcus aureus microbes (Razmavar et al. 2014). Khoirun Nisa et al., isolated three new compounds of acylphloroglucinols, baeckenones along with the known compounds. The isolated compounds exhibits moderate antimicrobial activity (Nisa et al. 2016).

Baeckea frutescens extracts were prepared by drying the parts of the plant at around $60^{\circ} \mathrm{C}$ in shade. The dried leaves are crushed and made into powder by grinding. The coarse particles were removed by sieving. Then the dried powder were used to extraction. Various solvents were used including, methanol, ethanol and aqueous solvents. The extracts were filtered in Whatman filter paper and the extracts after filtration were used for antimicrobial testing (Razmavar et al. 2014). 


\section{International Journal of Engineering Applied Sciences and Technology, 2020 Vol. 4, Issue 12, ISSN No. 2455-2143, Pages 199-204 \\ Published Online April 2020 in IJEAST (http://www.ijeast.com)}

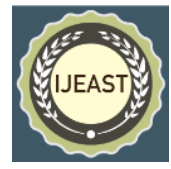

\section{Antimicrobial activity of Neem}

Azadirachta indica A (Neem) is a tree from the family of Meliaceae is wide spread in all over India. It is widely used to cure insect bites for its excellent pesticide activity. It is used to cure over 400 insect bites (Bina S. Siddiqui et al. 2004; Bina Shaheen Siddiqui et al. 2003). The plant has also has the pharmacological activities, such as anti-malaria, antiinflammatory, anti-fertility and antimicrobial (Dai et al. 1999; Subapriya and Nagini 2005). Tetranortriterpenoid is the active component of neem and it is abundant in the seeds of neem and it is present in leaves at smaller quantities. The neem has also salanin, nimboline, nimbin, azadiractol and Azadirachtin compounds. Over 300 components were isolated from neem (Dai et al. 1999; V. Sharma et al. 2003; Silva, Crotti, and Cunha 2007). Azadirachtin is the main component of neem for its biological activity (Alves et al. 2009).

The studies of antimicrobial activities on Neem showed good against the most pathogenic microbes. The leaves and seeds exhibits good antimicrobial activity against the microbes Escherichia coli and Staphylococcus aureus. Whereas, it is very poor against the microbes $S$. paratyphi, Bacillus subtillis, Candida albicans and S. desynteriae (Alhmad \& Beg, 2001). The Neem extracts were excellent against the most pathogenic fungi, Epidermophyton, Trichophyton, and Microsporum,((Alves et al. 2009). The aqueous extracts of neem leaf has the excellent antiseptic properties to cure wounds, swellings, soothes and used in skin problems (Raut, Sawant, and Jamge 2014).

N.A. Ibrahim et al., used neem oil in reactive print to impart antimicrobial activity on cotton and viscose fabrics. The print was exposed in alkaline condition to fix the reactive dye. The inclusion of bioactive compound, neem oil increases the antimicrobial activity against the pathogenic microbes E. coli and S. aureus. The antimicrobial activity is not affected by the type of reactive dye. The print with reactive dye look darker in shade when it is applied over the neem oil. The durability of antimicrobial activity of the finishing is confirmed after the 15 washes (Ibrahim, Eid, and El-Zairy 2011).

$\mathrm{M}$ joshi et al., used a natural bioactive agent, Neem to finish the polyester cotton blended fabric for its improvement in antimicrobial activity. He used glyoxal/glycol as crosslinking agent to improve the durability of the finishing. The aqueous extracts were prepared as per the standard procedure and applied on polyester and cotton blended fabric along with the crosslinking agent, glyoxal/glycol and Citric acid as catalyst in padding mangle by pad dry cure method. The padded fabric is dried at $60^{\circ} \mathrm{C}$ and cured at $150^{\circ} \mathrm{C}$ in curing chamber. The research identify that the increase in catalyst increase the crease recovery angle of the finished fabric. This may be the presence of citric acid act as a binder to increase the crease recovery angle. The increase the concentration of extract increase the antimicrobial activity. The durability performance was increased by the increase of crosslinking agents (Joshi, Ali, and Rajendran 2007).

K. Vaideki et al., used RF plasma treatment before the application of Neem extracts on cotton fabric to study the effect of RF plasma on antimicrobial activity. The plasma treatment increase the absorbency of azadirachtin compounds that increase the antimicrobial activity(Vaideki et al. 2008). Aparajita Verma at al., used neam leaves to synthesis of silver nanoparticles. The finished silver nano particles prepared from neem leaves produces the excellent antimicrobial activity (Verma and Mehata 2016).

\section{E. Antimicrobial activity of Eclipta Alba}

Asteraceae family of Eclipta alba also called as Bhringraja in local, a herbaceous medicinal plant known for its biological activities. In India, hepatitis are treated by Eclipta alba (Singh et al. 2001), it is also used to reduce the hair loss (Datta et al. 2009), anti venom for snake bite, and viral infections (Diogo et al. 2009). In Ayurveda, hepato related diseases like liver restore and other issues related to liver like liver ailments as well as hepatitis has been treated with Eclipta alba (Singh et al. 1993). Anti-HCV activities were cured using the Eclipta alba extract and the isolated compounds. It is used as a cholagogue and anti-blocking, jaundice and gall bladder (Orning et al., 1980). It is also has the power to enhance the memory and anti aging (Manvar et al. 2012). Wedelolactone and dimethyl wedelolactone compound were isolated from the Eclipta alba and used to blood thinning agent (Franca, Bertoni, and Pereira 1995; Wagner et al. 1986).

Khushwinder Kaur et al., used the methanolic extracts of false daisy to finish the cotton fabric for antimicrobial activity by direct and micro encapsulated methods. The methanolic extracts of false daisy were prepared by drying the leaves in shade and crushed into powder using mixer grinder. Then the powder were used for extraction in Soxhlet apparatus and methanol used as the solvent. The prepared methanol extracts were applied on cotton fabric in pad dry cure method with cross linking agent and micro encapsulation methods. The antimicrobial activity of the false daisy showed good in reduction of microbial growth in both direct method and micro encapsulated methods. The microencapsulated method showed good antimicrobial activity even after some washes (KAUR, BAINS, and GREWAL 2016).

\section{CONCLUSION}

Natural bioactive plant material is the alternative materials for synthetic non ecofriendly materials. These synthetic antimicrobial materials create lot of issues like non ecofriendly, cause side effects and so many. Whereas, the natural bioactive materials are ecofriendly, no side effects and available abundantly. In this paper, the antimicrobial activity of the various bioactive materials like Citrus lemon, Garlic, Baeckea frutescens, Neem and Eclipta Alba were described. Also the compounds which are present in the bioactive 


\section{International Journal of Engineering Applied Sciences and Technology, 2020 \\ Vol. 4, Issue 12, ISSN No. 2455-2143, Pages 199-204 \\ Published Online April 2020 in IJEAST (http://www.ijeast.com)}

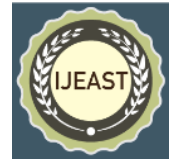

materials responsible for the antimicrobial are also listed. The extraction method and application of bioactive materials on textile materials are also enlisted.

\section{REFERENCE}

[1] Adetumbi, M., G. T. Javor, and B. H.S. Lau. 1986. "Allium Sativum (Garlic) Inhibits Lipid Synthesis by Candida Albicans." Antimicrobial Agents and Chemotherapy 30(3): 499-501.

[2] Alves, Priscila D., Maria G.L. Brandão, Elzíria A. Nunan, and Cristina D. Vianna-Soares. 2009. "Chromatographic Evaluation and Antimicrobial Activity of Neem (Azadirachta Indica A. Juss., Meliaceae) Leaves Hydroalcoholic Extracts." Brazilian Journal of Pharmacognosy 19(2 B): 510-15.

[3] Amer, M, M. Taha, and Z. Tosson. 1980. "The Effect of Aqueous Garlic Extract on the Growth of Dermatophytes." International Journal of Dermatology 19: 285-287.

[4] Burt, Sara. 2004. "Essential Oils: Their Antibacterial Properties and Potential Applications in Foods - A Review." International Journal of Food Microbiology 94(3): 223-53.

[5] Corbo, M. R. et al. 2008. "Study on the Synergic Effect of Natural Compounds on the Microbial Quality Decay of Packed Fish Hamburger." International Journal of Food Microbiology 127(3): 261-67.

[6] Dai, Jianming, Varoujan A. Yaylayan, G. S. Vijaya Raghavan, and Jocelyn R. Parè. 1999. "Extraction and Colorimetric Determination of Azadirachtin-Related Limonoids in Neem Seed Kernel." Journal of Agricultural and Food Chemistry 47(9): 3738-42. https://pubs.acs.org/doi/10.1021/jf990227h.

[7] Datta, Kakali et al. 2009. "Eclipta Alba Extract with Potential for Hair Growth Promoting Activity." Journal of Ethnopharmacology 124(3): 450-56. https://linkinghub.elsevier.com/retrieve/pii/S0378874109 003122.

[8] Dhanavade, Maruti J, Chidamber B Jalkute, Jai S Ghosh, and Kailash D Sonawane. 2011. "Study Antimicrobial Activity of Lemon (Citrus Lemon L.) Peel Extract." British Journal of Pharmacology and Toxicology 2(3): 119-22.

[9] Diogo, Luciana C. et al. 2009. "Inhibition of Snake Venoms and Phospholipases A 2 by Extracts from Native and Genetically Modified Eclipta Alba : Isolation of Active Coumestans." Basic \& Clinical Pharmacology \& Toxicology 104(4): 293-99. http://doi.wiley.com/10.1111/j.1742-7843.2008.00350.x.

[10] Duthie Garrya, and Crozier Alan. "Plant-Derived Phenolic Antioxidants." Current Opinion in Lipidology 11(1): 43-47.

[11] Franca, S. C., B. W. Bertoni, and A. M. S. Pereira. 1995. "Antihepatotoxic Agent in Micropropagated Plantlets of
Eclipta Alba." Plant Cell, Tissue and Organ Culture 40(3): $\quad$ 297-99. http://link.springer.com/10.1007/BF00048138.

[12] Fromtling R, and Bulmer G.S. 1978. "In Vitro Effect of Aqueous Extract of Garlic (Allium Sativum) on the Growth and Viability of Cryptococcus Neoformis." Mycologia 70: 397-405.

[13] Gattuso, Giuseppe et al. 2007. "Flavonoid Composition of Citrus Juices." Molecules 12(8): 1641-73.

[14] Huddleson I.F, DuFrain J, Barrows K.C., and Giefel M. 1944. "Antibacterial Substances in Plants." Journal of the American Veterinary Medicine 105: 394-412.

[15] Ibrahim, N. A., B. M. Eid, and E. R. El-Zairy. 2011. "Antibacterial Functionalization of Reactive-Cellulosic Prints via Inclusion of Bioactive Neem Oil/BCD Complex." Carbohydrate Polymers 86(3): 1313-19. http://dx.doi.org/10.1016/j.carbpol.2011.06.032.

[16] Ishikawa, Keiko et al. 1996. "Antimutagenic Effects of Ajoene, an Organosulfur Compound Derived from Garlic." Bioscience, Biotechnology and Biochemistry 60(12): 2086-88.

[17] J.A.Dukeand, and E.S.Ayensu. 1985. "Medicinal Plants of China." Medicinal Plants of the World 4.

[18] Jezpwa L, Rafinski T.J, and Wrocinski T. 1966. "Investigations on the Antibiotic Activity of Allium Sativum." Herba Polanica 12: 3-7.

[19] Joshi, M., S. Wazed Ali, and S. Rajendran. 2007. "Antibacterial Finishing of Polyester/Cotton Blend Fabrics Using Neem (Azadirachta Indica): A Natural Bioactive Agent." Journal of Applied Polymer Science 106(2): 793-800. http://doi.wiley.com/10.1002/app.26323.

[20] Kadhim Hindi, Nada Khazal, and Zainab Adil Ghani Chabuck. 2013. "Antimicrobial Activity of Different Aqueous Lemon Extracts." Journal of Applied Pharmaceutical Science 3(6): 74-78.

[21] KAUR, KHUSHWINDER, SANDEEP BAINS, and SUMEET GREWAL. 2016. "Development of Antimicrobial Finish from False Daisy (Eclipta Alba) for Cotton Fabric." Asian Journal of Home Science 11(1): 88-92.

[22] Kawaii, Satoru et al. 2000. "Quantitative Study of Flavonoids in Leaves of Citrus Plants." Journal of Agricultural and Food Chemistry 48(9): 3865-71.

[23] Keleş, Oya, Seyyal Ak, Tülay Bakirel, and Kerim Alpinar. 2001. "Screening of Some Turkish Plants for Antibacterial Activity." Turkish Journal of Veterinary and Animal Sciences 25(4): 559-65.

[24] Luigina Cellini et al. 1996. "Inhibition of Helicobacter Pylori by Garlic Extract (Allium Sativum)." FEMS Immunology and Medical Microbiology 13: 273-77.

[25] Manvar, Dinesh, Mahesh Mishra, Suriender Kumar, and Virendra N. Pandey. 2012. "Identification and Evaluation of Anti Hepatitis C Virus Phytochemicals from Eclipta Alba." Journal of Ethnopharmacology 


\section{International Journal of Engineering Applied Sciences and Technology, 2020 Vol. 4, Issue 12, ISSN No. 2455-2143, Pages 199-204 \\ Published Online April 2020 in IJEAST (http://www.ijeast.com)}

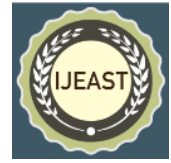

144(3):

$545-54$

http://dx.doi.org/10.1016/j.jep.2012.09.036.

[26] Marques, Antonio, Susana Encarnação, Sonia Pedro, and Maria Leonor Nunes. 2008. "In Vitro Antimicrobial Activity of Garlic, Oregano and Chitosan against Salmonella Enterica." World Journal of Microbiology and Biotechnology 24(10): 2357-60.

[27] De Moraes Pultrini, Aline, Luciane Almeida Galindo, and Mirtes Costa. 2006. "Effects of the Essential Oil from Citrus Aurantium L. in Experimental Anxiety Models in Mice." Life Sciences 78(15): 1720-25.

[28] Nisa, Khoirun et al. 2016. "New Acylphloroglucinol Derivatives from the Leaves of Baeckea Frutescens." Phytochemistry Letters 15: 42-45. http://dx.doi.org/10.1016/j.phytol.2015.11.011.

[29] Ortuño, A. et al. 2006. "Citrus Paradisi and Citrus Sinensis Flavonoids: Their Influence in the Defence Mechanism against Penicillium Digitatum." Food Chemistry 98(2): 351-58.

[30] Pandey, M. M., Subha Rastogi, and A. K.S. Rawat. 2013. "Indian Traditional Ayurvedic System of Medicine and Nutritional Supplementation." Evidencebased Complementary and Alternative Medicine 2013.

[31] Qutaba, Syed, B I N Tariq, Lubna Syed, and L I Zhaoling. 2017. "EVOLUTION OF ECO-FRIENDLY ANTIMICROBIAL FINISHES EXTRACTED FROM CITRUS FRUITS PEEL FOR TEXTILE COTTON FABRIC WITH FURTHERANCE DOMESTIC WASHING." 8(10): 973-79.

[32] Raut, Ranjit R, Ajit R Sawant, and Bhagyashree B Jamge. 2014. "Antimicrobial Activity of Azadirachta Indica (Neem) against Pathogenic Microorganisms." Journal of Academia and Industrial Research (JAIR) 3(December 2014): 327.

[33] Razmavar, Somayeh, Mahmood Ameen Abdulla, Salmah Binti Ismail, and Pouya Hassandarvish. 2014. "Antibacterial Activity of Leaf Extracts of Baeckea Frutescens against Methicillin-Resistant Staphylococcus Aureus.” BioMed Research International 2014.

[34] Rees, L. P. et al. 1993. "A Quantitative Assessment of the Antimicrobial Activity of Garlic (Allium Sativum)." World Journal of Microbiology \& Biotechnology 9(3): 303-7.

[35] S. Mardisiswojo, and H. Rajakmangunsudarso. 1985. Balai Pustaka, Jakarta, Indonesia Cabe Puyang Warisan Nenek Moyang.

[36] Setzer, William N. et al. 2004. "Antimicrobial Activity of Artemisia Douglasiana Leaf Essential Oil." Fitoterapia 75(2): 192-200.

[37] Shahanaz sultana, M Ali, S.H. Ansari, and Priyanka Bagri. 2007. "A New Sesquiterpene Derivative from the Fruit Peel of Citrus Limon(Linn.) Burm.F." Scientia Pharmaceutica 75: 165-70.

[38] Sharma, V.D, M.S Sethi, A Kumar, and J.R. Rarotra. 1977. "Antibacterial Property of Allium Sativum Lill: In
Vitro and in Vivo Studies." Indian Journal of Experimental Biology 15: 466-468.

[39] Sharma, Vandana et al. 2003. "An Efficient Method for the Purification and Characterization of Nematicidal Azadirachtins A, B, and H, Using MPLC and ESIMS." Journal of Agricultural and Food Chemistry 51(14): 3966-72. https://pubs.acs.org/doi/10.1021/jf0342167.

[40] Shashikanth, K. N., S. C. Basappa, and V. Sreenivasa Murthy. 1984. "A Comparative Study of Raw Garlic Extract and Tetracycline on Caecal Microflora and Serum Proteins of Albino Rats." Folia Microbiologica 29(4): 348-52.

[41] Siddiqui, Bina S., Farhana Afshan, Tahsin Gulzar, and Muddasar Hanif. 2004. "Tetracyclic Triterpenoids from the Leaves of Azadirachta Indica." Phytochemistry 65(16): 2363-67. https://linkinghub.elsevier.com/retrieve/pii/S0031942204 001906.

[42] Siddiqui, Bina Shaheen et al. 2003. "Tetracyclic Triterpenoids from the Leaves of Azadirachta Indica and Their Insecticidal Activities." CHEMICAL \& PHARMACEUTICAL BULLETIN 51(4): 415-17. http://joi.jlc.jst.go.jp/JST.JSTAGE/cpb/51.415?from $=\mathrm{Cr}$ ossRef.

[43] Silva, José de Paula da, Antonio Eduardo Miller Crotti, and Wilson Roberto Cunha. 2007. "Antifeedant and Allelopathic Activities of the Hydroalcoholic Extract Obtained from Neem (Azadirachta Indica) Leaves." Revista Brasileira de Farmacognosia 17(4): 529-32. http://www.scielo.br/scielo.php?script=sci_arttext\&pid= S0102$695 X 2007000400009 \& \operatorname{lng}=e n \& n r m=i s o \& t \operatorname{lng}=$ en .

[44] Singh, B. et al. 1993. "Hepatoprotective Effect of Ethanolic Extract OfEclipta Alba on Experimental Liver Damage in Rats and Mice." Phytotherapy Research 7(2): 154-58. http://doi.wiley.com/10.1002/ptr.2650070212.

[45] - 2001. "In Vivo Hepatoprotective Activity of Active Fraction from Ethanolic Extract of Eclipta Alba Leaves." Indian Journal of Physiology and Pharmacology 45(4): 435-41.

[46] Subapriya, R., and S. Nagini. 2005. "Medicinal Properties of Neem Leaves: A Review." Current Medicinal Chemistry-Anti-Cancer Agents 5(2): 149-56. http://www.eurekaselect.com/openurl/content.php?genre $=$ article \&issn $=1568$ -

$0118 \&$ volume $=5 \&$ issue $=2 \&$ spage $=149$.

[47] Tsao, S. M., and M. C. Yin. 2001. "In-Vitro Antimicrobial Activity of Four Diallyl Sulphides Occurring Naturally in Garlic and Chinese Leek Oils." Journal of Medical Microbiology 50(7): 646-49.

[48] Vaideki, K., S. Jayakumar, R. Rajendran, and G. Thilagavathi. 2008. "Investigation on the Effect of RF Air Plasma and Neem Leaf Extract Treatment on the Surface Modification and Antimicrobial Activity of Cotton Fabric." Applied Surface Science 254(8): 2472- 
78.

[49] Vankar, Padma S., and Dhara Shukla. 2012. "Biosynthesis of Silver Nanoparticles Using Lemon Leaves Extract and Its Application for Antimicrobial Finish on Fabric." Applied Nanoscience (Switzerland) 2(2): 163-68.

[50] Verma, Aparajita, and Mohan Singh Mehata. 2016. "Controllable Synthesis of Silver Nanoparticles Using Neem Leaves and Their Antimicrobial Activity." Journal of Radiation Research and Applied Sciences 9(1):

$109-15$. http://dx.doi.org/10.1016/j.jrras.2015.11.001.

[51] Viuda-Martos, M., Y. Ruiz-Navajas, J. FernándezLópez, and J. Pérez-Álvarez. 2008. “Antifungal Activity of Lemon (Citrus Lemon L.), Mandarin (Citrus Reticulata L.), Grapefruit (Citrus Paradisi L.) and Orange (Citrus Sinensis L.) Essential Oils." Food Control 19(12): 1130-38.

[52] Wagner, Hildebert et al. 1986. "Coumestans as the Main Active Principles of the Liver Drugs Eclipta Alba and Wedelia Calendulacea 1." Planta Medica 52(05): 37074. http://www.thieme-connect.de/DOI/DOI?10.1055/s2007-969188

[53] Waidulla N Al-Ani, Siba M Al-Haliem, and Nahla O Tawfik. 2010. "Evaluation of the Antibacterial Activity of Citrus Juices: An In Vitro Study." Al-Rafidain Dental Journal 10(2): 376-82.

[54] Yoshida, S. et al. 1987. "Antifungal Activity of Ajoene Derived from Garlic." Applied and Environmental Microbiology 53(3): 615-17. 